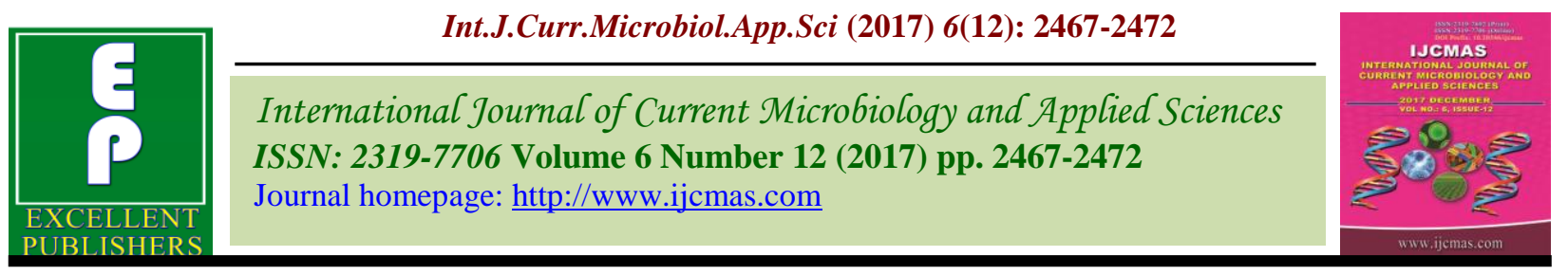

Original Research Article

https://doi.org/10.20546/ijcmas.2017.612.286

\title{
Effect of Different Crab Apples as Pollinizers on Fruit Quality of Apple under Kashmir Conditions, India
}

\author{
Rehana Javid $^{1 *}$, G. H. Rather ${ }^{1}$, Tawseef Rehman Baba', Jahangeer A. Baba ${ }^{2}$, \\ Mohammed Tauseef Ali $^{1}$ and Rahila Shameem ${ }^{1}$ \\ ${ }^{1}$ Division of Fruit Science, Sher-e-Kashmir University of Agricultural Sciences and Technology \\ of Kashmir, Shalimar, Srinagar 190025, India \\ ${ }^{2}$ DARS, Budgam J\&K, India \\ *Corresponding author
}

\begin{tabular}{|c|c|}
\hline & A B S T R A C T \\
\hline & The present study entitled "Pollination Compatibility among different Apple cultivars." \\
\hline Keywords & was carried out under Kashmir conditions, in an apple orchard of Department Of \\
\hline $\begin{array}{l}\text { Crabs, Pollen } \\
\text { compatibility, } \\
\text { Pollination, } \\
\text { Pollinizers. }\end{array}$ & $\begin{array}{l}\text { Horticulture, Pattan, district Baramulla during } 2014-2015 \text {. Four crab apple species (Malus } \\
\text { floribunda, Golden Hornet, Manchurian and Fenna) and Golden Delicious were used as } \\
\text { pollinizers for five apple cultivars (viz., Red Chief, Red Delicious, Red Fuji, Gala Mast } \\
\text { and Summer Red) and their functional pollen ability was determined. The highest fruit } \\
\text { weight was observed with the pollen of Malus floribunda }(189.60 \mathrm{~g} \text { ) followed by Golden }\end{array}$ \\
\hline Article Info & Delicious $(187.15 \mathrm{~g})$. The highest fruit length was observed with the pollen of Malus \\
\hline $\begin{array}{l}\text { Accepted: } \\
19 \text { October } 2017 \\
\text { Available Online: } \\
10 \text { December } 2017\end{array}$ & $\begin{array}{l}\text { floribunda }(6.82 \mathrm{~cm}) \text { followed by Manchurian }(6.73 \mathrm{~cm}) \text { and the lowest with that of Golden } \\
\text { Delicious }(6.29 \mathrm{~cm}) \text { irrespective of the varieties. Highest fruit diameter was observed with } \\
\text { the pollen of Golden Hornet }(6.38 \mathrm{~cm}) \text { followed by Manchurian }(6.36 \mathrm{~cm}) \text {. The overall } \\
\text { mean of the pollinizers reflects that the maximum length/diameter ratios of }(1.13 \mathrm{~cm}) \text { was } \\
\text { observed with the pollinizer Golden Delicious }\end{array}$ \\
\hline
\end{tabular}

\section{Introduction}

The cultivated apple Malus $\times$ domestica Borkh. is an interspecific hybrid complex of allopolyploid origin (Korban and Skirvin, 1984). The progenitor species is thought to be $M$. sieversii. Apple was introduced into the country by the British in the Kullu Valley of the Himalayan State of H.P. as far back as 1865, while the colored Delicious cultivars of apple were introduced to Shimla hills of the same State in 1917. Apple production is a result of series of physiological events including fruit set (Sanzol and Herrero, 2001). But one of the pressing problems today is decline in the quality and quantity of apples in the valley. There could be a number of reasons for declining apple production, but the most important which needs a quick attention is proper management for pollination in apples. Pollination is one of the keys to profitable apple production. Therefore it is important to select a pollinizer variety which has compatible pollen and an overlapping flowering period. Apple varieties are generally self-unfruitful and do not fruit by their own pollen due to the antagonism that prevents pollen grains from growing on 
to stigmas of the same variety. Genetically apples show gametophytic selfincompatibility (Thompson and Thompson, 1992) which necessitates the pollen transfer from another pollinizer variety to set fruit in marketable quantities. For cross pollination to be effective it is very important that the cultivars bloom at approximately the same time, produce the sufficient quantity of viable, compatible pollens.

Keeping this in mind Crab apples serve the purpose and can be considered as best pollinizers, particularly where a second variety is not desired, or the use of another variety will make management of the orchard more complicated. The common pollinizer used in apple orchards is Golden Delicious and Red Gold but it has been reported that these cultivars do not synchronize with Delicious group and bloom late which ultimately results in poor fruit set and quality. Further these pollinizers do not pollinate the king flower of the apple crop which has the inherent potential of producing the high value "A" grade fruit. On the other hand crab apples bloom early and remain blooming for a longer duration. To harness the benefit of early and long blooming period of these crab apples, the functional ability of pollen of different crabs was studied.

\section{Materials and Methods}

The experiment was conducted during 20142015 with an objective to find out the functional ability of pollen of different crabs. Full bearing exotic apple cultivars under high density plantation, uniform in age were selected for experimentation in apple orchard at Pattan. The trees were spaced at $3 \mathrm{~m} \times 1 \mathrm{~m}$ and laid in square system of planting, on $\mathrm{M}_{9}$ rootstock. The blossom of five apple cultivars viz., Red Delicious Red Chief, Red Fuji, Summer Red and Gala Mast were used as female parents while as the crab apples viz.,
Malus floribunda (A2)

Golden Hornet (A3)

Manchurian (A4)

Fenna (A5) and

Golden Delicious as control (A1) was used as pollen parents.

The fruit quality of five main varieties was tested with these pollinizers:

Red Delicious (control) (B1)

Red Fuji (B2)

Red Chief (B3)

Gala Mast (B4)

Summer Red (B5)

\section{Fruit weight}

The weight of fruits was calculated by weighing the representative sample of fruits on an electric balance, averaged and recorded.

\section{Fruit size}

Fruit size was determined by calculating the length and breadth of 10 samples with the help of Vernier caliper and calculating L/D ratios and expressed as centimeters $(\mathrm{cm})$.

\section{TSS}

The juice expressed from the apples was used to assess the TSS $\left({ }^{\circ}\right.$ Brix) with the help of digital hand Refractometer (Erma make japan).

\section{Seed number per fruit}

Seed content in each fruit was assessed by slicing the apples horizontally through the equatorial plane and the number of fully developed seeds were counted. 


\section{Results and Discussion}

\section{Fruit Weight}

The maximum fruit weight (197.99g) was recorded in 'Red Delicious x Golden Hornet' which was higher than the control(181.68g) and the minimum fruit weight of (146.21g) was recorded in 'Red Fuji x Manchurian'. (Table 1) Highest fruit weight was observed with the pollen of Malus floribunda (189.60g) followed by Golden Delicious (187.15g) and the lowest with the pollinizer Fenna (173.05) irrespective of the varieties. Manchurian as pollen parent when cross pollinated with other varieties has shown remarkable differences in terms of fruit weight, the results were found as per Keulemans et al., (1996) and Sharma et al., (2007) who stated that higher seed count is associated with higher sink strength in the fruit, which is reflected by an increase in fruit weight.

The highest fruit weight of $188.63 \mathrm{~g}$ was noticed in 'Red Chief $x$ Manchurian' followed by $186.50 \mathrm{~g}$ in 'Summer Red $\mathrm{x}$ Manchurian' with $183.86 \mathrm{~g}$ in 'Red Fuji x Manchurian' and $182.56 \mathrm{~g}$ in the cross combination of 'Red Delicious x Manchurian' and the lowest in 'Gala Mast x Manchurian' $(172.08 \mathrm{~g})$, the results are in consonance with Winfree et al., (2008). There were significant differences among the various crosses made as per the crossing plan.

\section{Fruit size}

\section{Fruit length (cm)}

The results show that the highest fruit length was observed with the pollen of Malus floribunda $(6.82 \mathrm{~cm})$ followed by Manchurian $(6.73 \mathrm{~cm})$ and the lowest with that of Golden Delicious $(6.29 \mathrm{~cm})$ irrespective of the varieties. (Table 2).The data reflected that all set of cross combinations had significant differences with each other, however data reveals that the pollinizer Malus floribunda and Golden Hornet were statistically at par with each other. Also no significant difference was observed between Malus floribunda and Manchurian. While as Malus floribunda showed significant differences with both Golden Delicious and Fenna.

\section{Fruit diameter $(\mathbf{c m})$}

The highest fruit diameter was observed with the pollen of Golden Hornet $(6.38 \mathrm{~cm})$ followed by Manchurian $(6.36 \mathrm{~cm})$ and $\mathrm{t}$ lowest with that of Fenna $(6.15 \mathrm{~cm})$ irrespective of the varieties.

Also all the pollinizers were statistically at par with each other (Table 3 ). The overall mean however revealed that the pollinizers Golden Hornet and Malus floribunda, Golden Hornet and Manchurian, Golden Hornet and Fenna and Golden Hornet and Golden Delicious were statistically at par.

\section{Length/diameter ratio of fruits}

The overall mean of the pollinizers reflects that the maximum length/diameter ratios of $(1.13 \mathrm{~cm})$ was observed with the pollinizer Golden Delicious followed by Golden Hornet and Manchurian (1.07) and minimum length/diameter ratio of $(1.06 \mathrm{~cm})$ with that of Malus floribunda and Fenna (Table 4).

\section{Seed number}

The results show that the highest seed number was observed with the pollinizer Malus floribunda (9.95) followed by Golden Hornet (9.80) and the lowest (8.45) when Fenna and Manchurian, were used as pollinizers irrespective of the varieties under study, also the pollinizers Malus floribunda and Golden Hornet; Manchurian and Fenna were statistically at par with each other. 
Table.1 Effect of pollen source on fruit weight (g)

\begin{tabular}{|c|c|c|c|c|c|c|}
\hline $\begin{array}{l}\text { Varieties } \\
\text { Pollinizers }\end{array}$ & $\begin{array}{l}\text { Red } \\
\text { Delicious }\end{array}$ & Red Fuji & Red Chief & Gala Mast & $\begin{array}{l}\text { Summer } \\
\text { Red }\end{array}$ & Mean \\
\hline Golden Delicious & 181.68 & 192.11 & 183.725 & 187.94 & 190.31 & 187.15 \\
\hline Malus floribunda & 195.07 & 193.73 & 181.94 & 189.13 & 188.11 & 189.60 \\
\hline Golden Hornet & 197.99 & 165.53 & 167.45 & 158.23 & 188.41 & 175.52 \\
\hline Manchurian & 181.59 & 146.21 & 197.67 & 155.38 & 187.47 & 173.67 \\
\hline Fenna & 195.77 & 187.87 & 191.68 & 143.82 & 148.37 & 173.37 \\
\hline Mean & 190.422 & 177.09 & 184.49 & 166.90 & 180.54 & 179.88 \\
\hline
\end{tabular}

Table.2 Effect of pollen source on fruit length $(\mathrm{cm})$

\begin{tabular}{|c|c|c|c|c|c|c|}
\hline $\begin{array}{l}\text { Varieties } \\
\text { Pollinizers }\end{array}$ & $\begin{array}{l}\text { Red } \\
\text { Delicious }\end{array}$ & Red Fuji & Red Chief & Gala Mast & $\begin{array}{l}\text { Summer } \\
\text { Red }\end{array}$ & Mean \\
\hline Golden Delicious & 6.99 & 5.86 & 6.64 & 5.65 & 6.35 & 6.29 \\
\hline Malus floribunda & 7.13 & 6.12 & 7.30 & 6.83 & 6.76 & 6.82 \\
\hline Golden Hornet & 6.86 & 5.86 & 7.20 & 6.68 & 6.73 & 6.66 \\
\hline Manchurian & 6.89 & 6.42 & 7.07 & 6.59 & 6.72 & 6.73 \\
\hline Fenna & 6.83 & 6.52 & 6.92 & 6.21 & 6.60 & 6.61 \\
\hline Mean & 6.94 & 6.15 & 7.02 & 6.39 & 6.63 & 6.60 \\
\hline $\begin{array}{l}\text { C.D. }(\mathrm{p} \leq 0.05) \\
\text { Pollinizer (P): } 0.17 \\
\text { Variety (V): } 0.17 \\
\text { P X V: } 0.39\end{array}$ & & & & & & \\
\hline
\end{tabular}

Table.3 Effect of pollen source on fruit diameter $(\mathrm{cm})$

\begin{tabular}{|c|c|c|c|c|c|c|}
\hline $\begin{array}{l}\text { Varieties } \\
\text { Pollinizers }\end{array}$ & $\begin{array}{l}\text { Red } \\
\text { Delicious }\end{array}$ & Red Fuji & Red Chief & Gala Mast & $\begin{array}{l}\text { Summer } \\
\text { Red }\end{array}$ & Mean \\
\hline Golden Delicious & 6.01 & 5.88 & 6.40 & 5.89 & 6.68 & 6.17 \\
\hline Malus floribunda & 6.24 & 6.01 & 7.10 & 6.28 & 6.06 & 6.34 \\
\hline Golden Hornet & 6.34 & 6.30 & 6.92 & 6.23 & 6.12 & 6.38 \\
\hline Manchurian & 6.12 & 5.84 & 7.19 & 6.48 & 6.16 & 6.36 \\
\hline Fenna & 6.32 & 6.08 & 6.45 & 5.79 & 6.11 & 6.15 \\
\hline Mean & 6.22 & 5.96 & 6.81 & 6.13 & 6.22 & 6.28 \\
\hline
\end{tabular}

C.D. $(\mathrm{p} \leq 0.05)$

Pollinizer (P): 0.25

Variety (V): 0.25

P X V: 0.56 
Table.4 Effect on pollen source on L/D Ratio

\begin{tabular}{|c|c|c|c|c|c|c|}
\hline $\begin{array}{l}\text { Varieties } \\
\text { Pollinizers }\end{array}$ & $\begin{array}{l}\text { Red } \\
\text { Delicious }\end{array}$ & Red Fuji & Red Chief & Gala Mast & $\begin{array}{l}\text { Summer } \\
\text { Red }\end{array}$ & Mean \\
\hline Golden Delicious & 1.10 & 1.21 & 1.03 & 1.25 & 1.06 & 1.13 \\
\hline Malus floribunda & 1.09 & 1.09 & 0.98 & 1.09 & 1.04 & 1.06 \\
\hline Golden Hornet & 1.06 & 1.08 & 1.04 & 1.07 & 1.09 & 1.07 \\
\hline Manchurian & 1.14 & 1.04 & 1.05 & 1.06 & 1.07 & 1.07 \\
\hline Fenna & 1.09 & 1.07 & 1.01 & 1.05 & 1.07 & 1.06 \\
\hline Mean & 1.09 & 1.10 & 1.02 & 1.10 & 1.06 & 1.07 \\
\hline
\end{tabular}

C.D. $(\mathrm{p} \leq 0.05)$; Pollinizer (P): 0.03; Variety (V): 0.03; P X V: 0.07

Table.5 Effect of pollen source on seed number

\begin{tabular}{lllllll}
\hline \multicolumn{1}{c}{ Varieties } & Red \\
Pollinizers & Red Fuji & Red Chief & Gala Mast & $\begin{array}{l}\text { Summer } \\
\text { Red }\end{array}$ & Mean \\
\hline Golden Delicious & 8.75 & 8.75 & 8.50 & 10.25 & 9.25 & 9.10 \\
Malus floribunda & 9.75 & 10.00 & 9.75 & 10.00 & 9.00 & 9.95 \\
Golden Hornet & 10.50 & 10.00 & 9.50 & 8.75 & 9.25 & 9.80 \\
Manchurian & 7.75 & 10.00 & 7.75 & 8.25 & 7.75 & 8.45 \\
Fenna & 10.50 & 7.75 & 8.25 & 9.25 & 6.50 & 8.45 \\
\hline Mean & 9.45 & 9.90 & 8.75 & 9.30 & 8.35 & 9.15 \\
\hline
\end{tabular}

C.D. (p $\leq 0.05$ ); Pollinizer (P): 0.46; Variety (V): 0.46; P X V: 0.10

Table.6 Effect of pollen source on TSS (Brix) of fruit

\begin{tabular}{|c|c|c|c|c|c|c|}
\hline $\begin{array}{l}\text { Varieties } \\
\text { Pollinizers }\end{array}$ & $\begin{array}{l}\text { Red } \\
\text { Delicious }\end{array}$ & Red Fuji & Red Chief & Gala Mast & $\begin{array}{l}\text { Summer } \\
\text { Red }\end{array}$ & Mean \\
\hline Golden Delicious & 13.23 & 12.48 & 13.66 & 13.13 & 12.35 & 12.97 \\
\hline Malus floribunda & 12.32 & 11.39 & 13.12 & 14.21 & 14.17 & 13.04 \\
\hline Golden Hornet & 11.56 & 11.82 & 10.72 & 14.77 & 13.25 & 12.43 \\
\hline Manchurian & 10.63 & 11.37 & 10.45 & 13.77 & 10.83 & 11.41 \\
\hline Fenna & 11.25 & 13.43 & 10.31 & 14.59 & 11.70 & 12.26 \\
\hline Mean & 11.80 & 12.10 & 11.65 & 14.09 & 12.47 & 12.42 \\
\hline
\end{tabular}

C.D. $(\mathrm{p} \leq 0.05)$; Pollinizer (P): 0.24; Variety (V): 0.24; P X V: 0.55

Kron and Husband (2006) reported that by increasing the diversity of compatible pollen enhanced seed number and reduced seed abortion is observed resulting in increased number of fruits.
The observations related to the seed number of Hand pollinated fruits of apple cultivars under study is recorded in Table 5. The number and distribution of seeds within a developing apple affects its shape and weight (Keulemans et al., 1996). 


\section{Fruit TSS (Brix)}

The highest fruit TSS was observed with the pollen of Malus floribunda $\left(13.04{ }^{0} \mathrm{~B}\right)$ followed by Golden Delicious $\left(12.97{ }^{0} \mathrm{~B}\right)$ and lowest $\left(11.41{ }^{0} \mathrm{~B}\right)$ with that of Manchurian irrespective of the varieties (Table 6).

It is evident from the data related to the fruit TSS that the maximum TSS $\left(14.77{ }^{0} \mathrm{~B}\right)$ was recorded in 'Gala Mast x Golden Hornet' which was higher than control $\left(13.13{ }^{0} \mathrm{~B}\right)$ i.e., 'Gala Mast x Golden Delicious' followed by $\left(14.59{ }^{0} \mathrm{~B}\right)$ in 'Gala Mast $\mathrm{x}$ Fenna' cross combination, however the minimum fruit TSS $\left(10.31^{\circ} \mathrm{B}\right)$ was recorded in 'Red Chief $\mathrm{x}$ Fenna' which was lower than the control $\left(13.36{ }^{0} \mathrm{~B}\right)$ in 'Red Fuji x Golden Delicious'.

All the crabs used as pollinizers in present study were found to be the effective pollen sources for pollination of apple cultivars viz., Red Chief, Red Fuji, Red Delicious, Gala Mast and Summer Red.

However, the best pollinizer in terms of pollen fruit quality was Malus floribunda and Golden Hornet. Malus floribunda and Golden Hornet proved to be the best pollinizers for all the cultivars under study The overall results indicate that the pollinizers Malus floribunda, Golden Hornet, Manchurian and Fenna possess promise in terms of various characters studied. It is therefore suggested from this study that crabs act as more effective pollinizers since they produce abundant number of viable and compatible pollens.

\section{References}

\section{How to cite this article:}

Rehana Javid, G. H. Rather, Tawseef Rehman Baba, Jahangeer A. Baba, Mohammed Tauseef Ali and Rahila Shameem. 2017. Effect of Different Crab Apples as Pollinizers on Fruit Quality of Apple under Kashmir Conditions. Int.J.Curr.Microbiol.App.Sci. 6(12): 2467-2472. doi: https://doi.org/10.20546/ijcmas.2017.612.286
Keulemans, J., Brusselle, A., Eyssen, R., Vercammen, J. and Daele, G. 1996. Fruit weight in apple as influenced by seed number and pollenizer. Acta Horticulturae, 423: 201-210.

Korban, S.S. and Skirvin, R.M. 1984. Nomenclature of the cultivated apple. Hort. Science., 19: 177-180.

Kron, P. and Husband, B.C.2006. The effects of pollen diversity on plant reproduction: insights from apple. Sexual Plant Reproduction, 19(3): 125131.

Sanzol, J. and Herrero, M. 2001. The effective pollination period in fruit trees. Science of Horticulture, 90: 1-17.

Sharma, H.K., Gupta, J.K., Jayant, K. and Rana, B.S. 2007. Attractiveness of different cultivars of crab apple to insect pollinators and their performance as pollinizer of commercial delicious apple. Indian Bee Journal, 69 (1/4): 4954.

Thompson, J.D. and Thompson, B.A. 1992. Pollen presentation viability schedules and their consequences for reproductive success through animal pollination. In: Ecology and Evolution of Plant Reproduction-New Approaches, pp. 124.

Winfree, R., Williams, N.M., Gaines, H., Ascher, J.S. and Kremen, C. 2008. Wild bee pollinators provide the majority of crop visitation across land-use gradients in New Jersey and Pennsylvania, USA. Journal of Applied Ecology, 45: 793802. 